\title{
Metastasis-Associated Protein MTA1
}

National Cancer Institute

\section{Source}

National Cancer Institute. Metastasis-Associated Protein MTA1. NCI Thesaurus. Code C92517.

Metastasis-associated protein MTA1 (715 aa, 80 kDa) is encoded by the human MTA1 gene. This protein plays a role in the modulation of transcription. 